\title{
Hybridikirjaston haasteet maatalousalojen tiedonhallinnassa
}

\author{
ETM Merja Kettunen ${ }^{1)}$ \\ ${ }^{1)}$ Viikin tiedekirjasto, Helsingin yliopisto, PL 62,00014 Helsingin yliopisto, merja.kettunen@ helsinki.fi
}

\section{Mikä on hybridikirjasto}

Hallitusohjelmassa olevan tietoyhteiskuntaohjelman 2003-2007 mukaan hallituskauden aikana turvataan monipuolisten ja laadukkaiden tieto- ja kirjastopalvelujen saatavuus ja vahvistetaan kirjastojen roolia tietoyhteiskunnan perustaitojen levittäjänä. Kirjastosta kehitetään monipalvelujärjestelmä, hybridikirjasto, joka on perinteisen ja digitaalisen kirjaston yhdistelmä. Se tarjoaa pääsyn maailmanlaajuiseen tietoon eri medioiden, aineistojen ja verkkojen välityksellä ja opastaa aineiston käytössä.

Helsingin yliopiston kirjasto- ja tietopalvelustrategiassa todetaan, että yliopistolakiin tuleva yliopiston kolmas tehtävä vahvistaa yliopiston yhteiskunnallisten tehtävien merkitystä ja se asettaa yliopiston kirjastolle uusia vaatimuksia. Uutena tekijänä tulee kansalaisen tasa-arvoisten tiedonsaantimahdollisuuksien turvaaminen ja kasvava tarve löytää kanava, joka turvaa yliopiston ulkopuolisten tahojen tieteellisen tiedon saantimahdollisuudet.

Helsingin yliopiston kirjastot on koordinoitu kokonaisuus, jonka budjetti on 2,7 milj. € vuodessa. Kampuskirjastot keskittyvät kampusten tieteenalojen palvelemiseen. Viikin tiedekirjasto profiloituu entistä vahvemmin toisaalta kampuksen palvelukirjastoksi ja toisaalta valtakunnalliseksi alojensa tietokeskukseksi yliopistojen kolmannen tehtävän mukaisesti.

\section{Maatalousalan tutkija tiedonlähteillä}

Tieteellisen kirjallisuuden kartoitus on muuttunut paljon parissa kymmenessä vuodessa. Ennen tietoa haettiin joko painettujen aiheittaisten abstraktijulkaisujen viitelistoista tai käymällä läpi artikkeleiden kirjallisuusluetteloita. Periaatteessa näin toimitaan edelleen. Käytännössä tietoa haetaan nyt joko sähköiseen muotoon siirretyistä viitetietokannoista kuten kotimainen eViikki tai kansainvälinen CAB (Commonwealth Agricultural Bureau), jolloin alkuperäisen tiedon lähteille pääsee vasta hakemalla painettu julkaisu käsiinsä tai suoraan kustantajien hallinnoimista elektronisista lehdistä, jotka ovat kokoteksteinä ja koneelta printattavissa.

Kotimainen alan merkittävä tiedonlähde on eViikki, jonka ylläpidosta Viikin tiedekirjasto vastaa ja se on jatkuvan kehitystyön alla ( http://www-db.helsinki.fi/eviikki/eVIIKKIfreimi.html ). Se on maksutta kaikkien käytettävissä internetissä. Tietokannassa on n. 265000 kirja- ja artikkeliviitettä. Viitteet on asiasanoitettu, joten aiheenmukainen haku onnistuu. Tietokannassa olevista julkaisuista on myös linkki Helkaan, Helsingin yliopiston kirjastoluetteloon, josta näkee julkaisun saatavuustiedot.

Maatalousalojen ehkä merkittävin kansainvälinen viitetietokanta CAB on Helsingin yliopistolaisten käytettävissä verkossa, johon muut pääsevät käsiksi kirjastossa tai käyttämällä tietopalvelua apuna. Viitteet, joiden määrä lisääntyy vuositasolla n. 200 000:1la, sisältävät pääosin myös tiivistelmän. FAO:n ylläpitämä Agris -tietokanta on internetissä käytettävissä ilmaisversiona http://www.fao.org/agris/ . Agriksella on hajautettu tuotanto, Viikin tiedekirjasto on mukana yhtenä viitteiden tuottajana.

Paljon kansainvälisesti merkittäviä alan kausijulkaisuja on käytettävissä elektronisessa muodossa Helsingin yliopiston yhteisessä E-lehdet -tietokannassa http://ejournals.helsinki.fi/. Haku tehdään suoraan kokotekstiviitteestä. Tarkkojen sopimusten takia yliopiston ulkopuolisten asiakkaiden pääsy näihin julkaisuihin onnistuu parhaiten kirjastossa paikan päällä. Maatalousalan tiedonlähteet on koottu yhteen Viikin tiedekirjaston kotisivustolle http://www.tiedekirjasto.helsinki.fi/tiedonhaku/maataloustieteet.htm .

\section{Kokoelmapalvelut Viikin tiedekirjastossa}

Tärkeänä tiedonlähteenä toimivat kirjastomme monitieteiset kokoelmat, joita on n. 13700 hyllymetriä. Määrästä lähes puolet sijaitsee asiakkaiden helposti käytettävissä Infokeskuksessa ja loput kampuksella sijaitsevissa etävarastoissa. Kokoelmat perustuvat entisten keskuskirjastojen, Maatalouskirjaston ja Metsäkirjaston, kokoelmiin sekä Biokeskuksen kirjastojen ja Luonnontieteiden kirjaston laaja-alaisiin biotieteellisiin kokoelmiin. Viimeksi mainitun perustana on ollut Tieteellisten seurojen kirjasto. Vuonna 2002 kirjastoomme liittyi ekologian ja systematiikan laitoksen eläintieteen ja kasvitieteen kirjastot sekä biotieteiden laitoksen eläinfysiologian kirjastot kokoelmineen. Vuonna 2004 Viikin tiedekirjastoon liittyy vielä eläinlääketieteellinen kirjasto, jonka kokoelmat ovat Suomessa ainutlaatuiset ja täydentävät siten Viikin tiedekirjaston nykyisiä kokoelmia. 
Painettuja kausijulkaisunimekkeitä tulee kirjastoomme runsaat $4000 \mathrm{kpl}$, joista ostettuja on $660 \mathrm{kpl}$. Suurimman osan painetuista kausijulkaisunimekkeistä saamme kokoelmiimme vaihtoina tai lahjoituksina. Kirjastomme on suurin Tieteellisen kirjallisuuden vaihtokeskuksen asiakas ja saamme sitä kautta kokoelmiimme n. 2000 jatkuvasti tulevaa nimekettä, mikä on $28 \%$ vaihtokeskuksen kautta Suomeen tulevista aineistoista. Helsingin yliopiston kirjastojen kokoelmaluettelo Helka on käytettävissä mistä vaan osoitteessa http://helka.linneanet.fi/. . Helkassa on kaikki Viikin tiedekirjaston kausijulkaisut ja suurin osa kirjoista. Osa vanhoista kirjoista on löydettävissä vain käyttämällä kirjaston pahvikortistoa.

Painettujen julkaisujen lisäksi kirjastomme kotisivujen ja yliopiston E-lehdet -tietokannan kautta on pääsy n. 10000 elektroniseen lehteen, josta suurimman osan saamme käyttöön osana kansallista FinElib konsortiota. Tietokantaa ylläpidetään yhteistyössä eri Helsingin yliopiston kirjastolaitoksen osien kesken. Päätös painettujen rinnakkaisversioiden lakkauttamisesta FinElib-sopimuksen piiriin kuuluvien lehtien osalta syksyllä 2001 siirsi kirjastomme lopullisesti elektroniseen aikakauteen..

Tietoaineiston hankinnassa teemme tiivistä yhteistyötä erityisesti Viikin kampuksen laitosten kanssa. Kausijulkaisuhankinnat tehdään laitosten asettamien priorisointien mukaan. Tietoaineistojen hankinnassa ja kustannusten jaossa teemme yhteistyötä yliopiston kampuskirjastojen, terveystieteiden kirjaston (Terkko) ja Kumpulan tiedekirjaston, kesken. Yhteistyönä on hankittu myös huomattava määrä elektronisia hakuteoksia ja BioMedCentral-palvelu koko yliopiston käyttöön.

Kirjastomme toimii Viikin kampuksen opiskelijakirjastona ja näin ollen hankimme kokoelmiimme vuosittain laitosten esittämät kurssikirjat ja muuta kirjallisuutta.

\section{Yliopiston ulkopuolisten tahojen palvelut}

Kaukopalvelu ( http://www.tiedekirjasto.helsinki.fi/palvelut/kaukopalvelu.htm ) on perinteinen palvelumuoto yliopiston ulkopuolisille asiakkaille sen lisäksi, että kaikki ovat tervetulleita käyttämään paikallispalveluitamme. Lähetämme asiakkaille artikkeleita joko kopioina tai digitaalisesti sekä kirjoja lainaan joko omista kokoelmista tai välittävänä kaukopalveluna toisista kotimaisista tai ulkomaisista kirjastoista palveluhinnaston mukaan. Kaukopalvelu toimii pääasiassa asiakkaan organisaation kirjaston tai tietopalvelun kautta tai yksityishenkilöille kunnan kirjaston kautta.

Isona osana tarjoamaamme palvelua on tietoaineiston etäkäyttö esim.. eViikki-, Helka- ja E-lehdet-tietokannoista. Viimemainittu toimii useiden elektronisten lehtien osalta myös tiedonhakuvälineenä, vaikka lisensioinnin vuoksi kokotekstit aukeavat vain yliopiston verkosta.

Helsingin yliopiston ulkopuolisille asiakkaille järjestämme räätälöityä tiedonhaun ja -hallinnan koulutusta sekä annamme konsultointiapua tiedon ja tietoaineiston järjestämisessä. Myös osallistuminen kirjaston vakiokursseille osallistumismaksua vastaan on mahdollista.

Kirjasto tekee organisaatioiden kanssa palvelusopimuksia, joissa sovitaan organisaation toivoma palveluvalikoima ja hinnoittelu.

\section{Uusi käyttöliittymä}

Vuoden 2004 alusta käyttöönotettava Nelli-portaali (National Electronic Library Interface) on kansallinen tiedonhakujärjestelmä, jolla haun voi kohdistaa useisiin eri tietokantoihin yhtäaikaa. Nelliä käytetään asiakkaiden tunnistamiseen ja se tarjoaa asiakkaille myös personoituja palveluita (oma aineistolista ja henkilökohtainen e-kirjahylly). Tiedonhakuportaali toteutetaan Metalib-ohjelmistolla. Tämä tulee helpottamaan tiedonhakua kokoamalla kaikki tiedonlähteet samalle sivulle.

\section{Hybridikirjaston hyvät puolet}

Asiakkaat ovat olleet iloisia elektronisten kausijulkaisujen tulosta. Tutkimustyö edistyy nopeassa tahdissa kun artikkelit saa nopeasti omalle tietokoneelle 24 tuntia vuorokaudessa ja näin lähteiden hakuun käytettävä aika minimoituu. Elektroninen aineisto tuo helpotusta myös kirjastoille. Säästöä syntyy tilakustannuksissa kun hyllytilan tarve vähenee. Hyvä asia on myös, että elektroniset julkaisut eivät mene huonoon kuntoon mekaanisesti kuten paperi. Kustantaja pitää huolen konversioista uusiin järjestelmiin säännöllisin väliajoin. Hyllyssä paperin ja sidosten/nidosten laatu sekä varaston ilman laatu vaikuttaa siihen kuinka kauan julkaisu pysyy ehjänä ja käyttökelpoisena.

\section{Hybridikirjaston ongelmat}

Ongelmana yliopiston ulkopuolisille käyttäjille on konsortioiden ja kustantajan väliset sopimukset, joissa e-lehtien käyttöoikeus on rajoitettu organisaatiokohtaiseksi. Tällöin myös kaukopalvelu joutuu 
noudattamaan näitä sopimuksia, ja artikkelit on järjestettävä asiakkaalle muuta kautta. Sopimukset ovat tiukkoja kaukopalvelun osalta erityisesti yrityksiin päin. Paikalliskäyttö kirjastossa on kuitenkin aina mahdollista.

Kokoelmien kannalta ollaan myös hyvin riippuvaisia kustantajista kun kirjasto ei saa konkreettisesti julkaisua omaan hyllyynsä. Julkaisut sijaitsevat kustantajan palvelimella. Ei ole enää itsestään selvää, että kerran maksettu vuosikerta on aina tulevaisuudessakin käytössä. Tämän takia tukeudutaan mielellään kansalliseen elektroniseen kirjastoon, FinElibiin, joka käy sopimusneuvottelut kustantajien kanssa ja sopii pitkäaikaiskäytöstä ( http://www.lib.helsinki.fi/finelib/).

\section{Open Access -palvelut}

Tieteellisten kausijulkaisujen kustannustoiminnassa tapahtuu koko ajan muutoksia; kustantamot fuusioituvat ja lehdet siirtyvät kustantajalta toiselle. On sanottu, että jokaisen fuusion yhteydessä lehtien hinnoissa tapahtuu selvä korotus. Kirjaston kannalta tästä seuraa tietenkin isot kustannukset suoraan ja myös välillisesti työkuluina kun ylläpidetään linkkejä lehtiin ajantasaisina.

Vastavetona jatkuvalle kustannusten kohoamiselle ja julkaisutoiminnan hitaudelle on tiedeyhteisöissä virinnyt ajatus saada artikkelit nopeasti verkkoon ilman kustantajan välikäsiä. Artikkelit ovat heti ja pysyvästi saatavilla arvioinnin ja julkaisemisen jälkeen ilman maksuja ja muita käytön esteitä. Perinteiseen julkaisutoimintaan perustuva julkaiseminen pikemminkin estää kuin edistää nopeaa tutkimustulosten välittämistä.

Esimerkkeinä Open access -palveluista on lääketieteellisiin ja biotieteellisiin kausijulkaisuihin keskittyvä BioMedCentral http://www.biomedcentral.com/home/ ja Directory of Open Access Journals http://www.doaj.org/ , käsittää kaikki tieteenalat ja kielet. Näissä on jo mukana yli 700 kausijulkaisunimekettä. Voi vain toivoa, että näiden painoarvo lisääntyisi. Artikkelit käyvät läpi "peer review" -arvioinnin normaaliin tapaan ennen kuin ne hyväksytään julkaistaviksi.

\section{Tiedonhallinnan apuvälineet}

Tieteellisen julkaisun kirjoittamisen helpottamiseksi on kehitetty viitteiden hallintajärjestelmiä. Tästä esimerkkinä on Helsingin yliopistolla käytössä oleva viitteiden hallintajärjestelmä RefWorks.. Se luo mahdollisuuden poimia viitteet internetissä olevasta tietokannasta tutkijan omaksi tietokannaksi ja muokata ne parissa sekunnissa kunkin lehden vaatimalle formaatille.

\section{Lopuksi}

Tutkijoille on siis tarjolla nykyään paljon eri tyyppisiä lähteitä. Valtaisan elektronisen aineiston tarjonnan sokaisemana ei pidä kuitenkaan unohtaa, että vanhaankin kirjallisuuteen kannattaa perehtyä, pyörää ei kannata keksiä uudestaan. Vanhan kirjallisuuden löytäminen vaatii joskus hieman vaivaa, esim. pahvikorttien selaamista tai vanhojen lähdeluetteloiden läpikäymistä, mutta vaiva saattaa kannattaa. Eri tieteenalat ovat tässäkin suhteessa varmasti erilaisia.

Kirjastossamme on käynnistynyt vanhan aineiston digitointiohjelma, jossa kokoelmissamme olevaa vanhaa arvokasta aineistoa digitoidaan skannaamalla HY:n Mikkelin toimipisteessä. Tästä hankkeesta ensimmäiset tulokset, 19 vanhaa metsäalan julkaisua, on nähtävillä kotisivustollamme http://www.tiedekirjasto.helsinki.fi/digi/ . Myös vanhan maatalousaiheisen kirjallisuuden takautuvaa luettelointia tehdään jatkuvasti Helka-tietokantaan. 